\section{DE DE GRUYTER} OPEN
Journal of Intercultural Management

Vol. 6, No. 2, April 2014, pp. 63-72

DOI 10.2478/joim-2014-0012

\author{
Agnieszka Wróblewska-Kazakin \\ Częstochowa University of Technology
}

\title{
Research on family businesses in Poland
}

\begin{abstract}
The purpose of this article is to present the research on family businesses in Poland commissioned by the Polish Agency for Enterprise Development. The study allowed for estimating the share of family businesses in the MSME sector and for identifying the differences in the functioning of family and non-family businesses in the Polish economy. Training and advisory services designed for family businesses thanks to the study resulted in development of tools specifically adjusted to the features of this group of enterprises, supporting their organizational, financial and legal aspects. The article also discusses two innovative tools developed as part of the Przewodnik po sukcesji [A Guide on Succession] and Kody wartości [Codes of Values] projects, allowing for independent completion of a succession process.
\end{abstract}

Key words: family business, management in family business, succession in family business, EU projects

\section{Introduction}

In the early 1990s, during the period of political and economic transformation in Poland, thousands of private enterprises were established, mainly in the MSME sector. The number of private enterprises registered in the REGON National Business Registry was $494 \mathrm{k}$ in 1991, and this number increased to $3.852 \mathrm{k}$ in 2012 [GUS 2013, p. 31]. That same year, there were $1.795 \mathrm{k}$ active non-financial enterprises registered in Poland, of which $95.8 \%$ were microenterprises, $3.1 \%$ were small enterprises, and $0.9 \%$ were mediumsized companies [GUS 2014, p. 22].

Hence, the MSME sector adds up to $99.8 \%$ of all Polish enterprises, while a considerable number of those are family businesses. The PARP [Polish Agency for Enterprise Development] data [2009, p. 27] shows that family businesses currently amount to $36 \%$ of the MSME sector. The percentage of 
microenterprises is $30 \%$, that of small enterprises - 28\%, and medium-sized companies - 14\%. The 2009 PARP research excluded entities operating in such areas as: agriculture, hunting, fishing, public administration, households giving employment to other people, as well as extraterritorial organizations and bodies. Also excluded were entities operating business transactions as natural persons running economic activity without giving employment to others. Should the latter be included in the definition of family business, the percentage would go up to $78 \%$, and should we also add agricultural businesses providing employment to their owners - this share would increase even up to 90\% [PARP 2012, p. 12].

The founders - the still present owners of family businesses - reach an age when they begin to consider limiting or even terminating their business activity. They ponder upon who and how should succeed them in power and ownership, how to secure their future well-being, whether they are ready for universal succession or should singular succession suffice for the time being. Therefore, the issues of succession are soon to become very common. However, due to the lack of private entrepreneurship in post-war Poland, there is no deep-rooted tradition of multi-generation companies, and the knowledge on succession is scarce. Most family business owners are not even aware of the existence of succession strategies developed thanks to scientific studies (of course, based on the practices of family businesses in economically developed countries, such as the United States or Switzerland). Only one in three Polish family businesses has developed a succession plan but only one in ten has such a plan drafted in writing [PARP 2009, p. 132].

\section{Beginnings of study of family businesses}

Research on family businesses commenced in the second half of the 1970s. The first important studies within this scope commenced in the developed countries, in particular, in the US, in the 1990s, on a representative sample of 14 thousand households [PARP 2009, p. 5]. Therefore, it may be assumed that the new discipline - study of family business - was distinguished at the end of the $20^{\text {th }}$ century.

The importance of family entrepreneurship in economy was also noticed in the European Union. In 2007, the European Commission appointed an expert group on Family Business, composed of representatives of all the EU Member States. In 2009, the final report compiled by the expert group [European Commission 2009] stated that family businesses share numerous aspects typical of that group of enterprises, despite the fact that most of the issues of family businesses are identical to those experienced in the MSME sector. Such issues may be divided into three categories:

1. Issues related to the external environment in which they operate. 
2. Issues related to the external affairs and relationships between the family and the company.

3. Issues related to educational aspects.

The first category encompasses all financial matters related, for example, to the inheritance and donation tax, access to funds which would not lead to losing control of the company, and privileged approach to reinvested funds.

The second category focuses mainly on the early unawareness of the necessity of a planned intergenerational transfer, difficulties with acquisition and maintenance of qualified employees, as well as the requirement of maintaining stability between the three elements comprising the idea of a family business, i.e., family, ownership and business.

The issues included in the third category draw attention to the lack of business education targeted at the specificity of a family business and to the need for more studies and analyses of family entrepreneurship.

In Poland, the awareness of the significance of family businesses in economic and social life is relatively recent. In 2005, on the initiative of Wyższa Szkoła Biznesu - National-Louis University in Nowy Sącz, the first Polish Conference on Family Business was held. In 2008, Stowarzyszenie Inicjatywa Firm Rodzinnych ["Family Business Initiative" Association] was registered in Warsaw, while 2011 was the year when Fundacja Firmy Rodzinne [Family Business Foundation] was established in Poznań. Before 2009, there was no reliable information in Poland on the number, ownership forms, structures or share of family businesses in the Polish economy. The first large-scale research on family business was conducted by Pentor Research International, commissioned by the Polish Agency for Enterprise Development within the framework of the Human Capital Operational Programme in cooperation with Stowarzyszenie Inicjatywa Firm Rodzinnych. The basic purpose of the study was to provide information on the necessities and problems of family businesses in order to design training and advisory services which would answer the family businessspecific needs, and, at the same time, to fill in the existing information gap concerning the share of family businesses in the MSME sector and their characteristic features in relation to non-family businesses [PARP 2009, pp. 8-9].

\section{Detailed description of the PARP research}

The above-mentioned research was commissioned by the Polish Agency for Enterprise Development and was co-financed by the European Social Fund within the framework of the Human Capital Operational Programme, Priority II, Measure 2.1, Sub-measure 2.1.3.

The Human Capital Operational Programme, specified in the 2007-2013 National Cohesion Strategy, stipulated, inter alia, improvement of adaptation 
potential and competitiveness of enterprises through investing in education and development of skills of Polish entrepreneurs. What appears indispensable within this scope is the inclusion of social partners and adjustment of the training system to the requirements of the labor market, as well as increasing the scale of knowledge transfer through supporting the cooperation of science and economy. These goals were specified in Priority II: Development of human resources and adaptation potential of enterprises and improvement in the health condition of working people.

The support granted within this Priority was directed to the MSME sector which, due to its operational specificity, limited financial resources and limited number of employees, face greatest challenges in the area of identification of needs, selection of adequate form and execution of development plans, including training policies [Ministerstwo Rozwoju Regionalnego 2013, p. 165].

The PARP project was carried out within the framework of Measure 2.1 of said Priority: Development of human resources for modern economy, aimed at implementation of supra-regional training and advisory projects for MSME enterprises. This is a systemic project, co-financed from the European Social Fund within the scope of Sub-measure 2.1.3: System support for increasing the adaptation potential of employees and entrepreneurs [www.kapitalludzki.gov.pl].

The main purpose of the study was to design training and advisory services for the family business group. The research comprised three stages [PARP 2009]:

1. Exploratory stage.

2. Identification and verification stage.

3. Explanatory stage.

The exploratory stage consisted in detailed analysis of the available studies on family business and quantitative research on a representative sample of 1280 MSME enterprises [PARP 2009, p. 17]. This was indispensable for a comparative analysis of family and non-family businesses. The purpose of this stage was to estimate the share of family businesses in the MSME sector according to diverse criteria of definition of a family business applied worldwide. For the purposes of further stages of the research, the first stage allowed to determine the following definition of a family business:

"a family business is any economic entity belonging to the sector of micro, small and medium-sized enterprises, of any legal status, registered and operating in Poland, where:

- at least two family members work together,

- at least one family member has a considerable influence on its management,

- family members hold shares" [PARP 2009, p. 20]. 
The identification and verification stage included qualitative research encompassing individual in-depth interviews with owners or co-owners of MSME operating as family businesses, as well as with key workers employed in family businesses. Such interviews were conducted in 30 family companies.

The main purpose of the explanatory stage was to develop a model of training and advisory scheme for family businesses.

The analyses conducted showed that the main differences between family and non-family businesses relate mostly to the sphere of values and organizational culture. One essential factor distinguishing family businesses from other enterprises of the MSME sector is the issue of intergenerational transfer. 58\% of family entrepreneurs are willing to transfer the company to the next generation, however, this appears to be solely a general declaration and not a well-defined succession plan [PARP 2009, p. 34]. Knowledge of the area of succession planning seems to be very limited. The owners, mostly still the founders of family businesses, act exclusively on their own experience and intuition, postpone the moment of company transfer, and perceive succession as a naturally occurring process. To a large extent, the researched companies would be facing a serious succession problem is succession resulted from a sudden, unforeseen event.

As a result, family businesses have not developed methods of preparing a potential successor to take over the company management, legal solutions facilitating succession, or mechanisms securing the interests of the retiring seniors. Only $32 \%$ of the researched family businesses declared to have a succession plan, while only one in ten has executed such plan in the form of a written document. Among medium-sized companies, the percentage of enterprises with no succession strategy was $52 \%$, among small enterprises $65 \%$, and among microenterprises - 69\% [PARP 2009, p. 156].

Unfortunately, the research shows that entrepreneurs do not feel the need for training within this scope.

The above-presented research results are dated 2009. At that time, is was indicated that Poland did not have a training and advice market designed for the specific group of the MSME sector, namely, for the family businesses, while the developed training and advisory services were the first ones addressed to that target group on the Polish market.

Since then, the awareness of the family aspect of Polish enterprises increased considerably. Family businesses established in the 1990s are currently managed by 60 -year-olds who ever more often consider retirement and transfer of company management to their successors. Therefore, the need for acquiring knowledge on succession is a result of expediency, however, also important is the promotion of the values and organizational culture 
introduced by family businesses into the economic and social life. One of the vital stimuli was the implementation of a pilot project in training and advisory services within the framework of cooperation between the Polish Agency for Regional Development and Stowarzyszenie Inicjatywa Firm Rodzinnych. The Firmy Rodzinne [Family Business] Project is the first enterprise to emphasize the family aspect of business as the supreme value. Educational activities organized as part of the project involved 300 people from over 100 companies. Those included both seniors - company founders, their family members, potential successors, as well as key employees from outside the family. The training and advisory sessions were held from May 2010 until the end of 2011. Project participants declared they felt proud of being part of the family business community and they realized how much they had been through when building a business from scratch and managing it in times of much difficulty for private entrepreneurship [Mączyńska M., PARP 2012, p. 16]. Project participants attended diverse workshops and training conferences, thematic meetings, and had the opportunity to avail of consulting services and meetings with mentors.

The basic assumption of the project was the idea that the foundation of any training activities lies in the development of communication, self-awareness, systemic thinking and modern management [Jakubowski J., PARP 2012, p. 101]. The educational paradigm, serving as the basis for the actions of the project authors, was expressed in the following theses [Jakubowski J., PARP 2012, p. 101]:

1. Participants are considered as partners aware of their self-responsibility for their education and development.

2. Coaches and consultants create educational situations where the participants (not students) "learn" and subjectively undertake development actions.

3. Values such as dignity, kindness, dialogue, freedom of choice, are the basis for the workshop procedures, educational and counselling programmes.

4. Workshops are conducted with the application of active methods (experience-based learning), while the necessary knowledge is delivered through interactive lectures.

5. The programme is constructed on the basis of preliminarily identified needs but it is subject to on-going modification resulting from observation and assessment of the activities and results.

To conclude, Firmy rodzinne was a pilot project whose goal was to develop and practically verify the methodology aimed at supporting family businesses in Poland. It involved three stages. The first stage consisted in research on family businesses in Poland with the purpose of identifying the training needs of this group of enterprises. The second stage involved cooperation of PARP and the 
IFR Association, comprising development of a set of methods of supporting family business and their practical implementation through training and advisory services. The third stage was the edition of the work entitled Firma w rodzinie czy rodzina $w$ firmie - metodologia wsparcia firm rodzinnych [PARP 2012].

\section{Tools for supporting succession in the Polish family businesses}

Among the most important areas of the training and advisory activities, which ought to be dedicated to family businesses in the nearest future, are the following:

1. Company preparation for transfer - legal and financial aspects.

2. Education and preparation of the successors for taking over the family business.

3. Personalization of business and human resources management in a family business [PARP 2009, p. 52].

Thanks to the PARP project, the first tools for supporting succession in the Polish family businesses were developed.

The first of said tools is Przewodnik po sukcesji w firmach rodzinnych [A Guide on Succession in Family Businesses], realized by PM Doradztwo Gospodarcze, the second is Kody wartości - efektywna sukcesja w polskich firmach rodzinnych [Codes of Values - efficient succession in Polish Family Businesses], realized by Centrum Rozwoju Szkół Wyższych TEB Akademia Sp. z o.o., Business Discovery Adrianna Lewandowska, and Hortimex Plus Sp. z o.o. s.k. Both projects were co-financed from the European Social Fund within the framework of the Human Capital Operational Programme, Priority II, Measure 2.1, Sub-measure 2.2.1: Development of human capital in enterprises.

The purpose of the projects was to develop and verify the efficiency of the innovative tool allowing for unassisted preparation of succession plans in family businesses. This appears a vital aspect, as $94 \%$ of the Polish family businesses are managed individually by their owners, while the remaining share is managed by the owners through other family members. Only a very small number of enterprises are managed by an external manager [PARP 2009, p. 133]. Therefore, the priority in creating training and advisory services was to develop such tools which would help solve succession problems individually.

The Przewodnik po sukcesji [A Guide on Succession] tool, developed as a result of the project, is composed of the following elements:

- Compendium on succession - 3 options: traditional book, multimedia version and audiobook, including educational materials, animations, interactive exercises, videos, etc.

- Two computer applications:

- Analytical and diagnostic app NOE - involves introducing into the system objective company data concerning financial, legal, organizational 
and personal information and subjective opinions of the owners. As a result, the entrepreneur obtains an automated analysis and diagnosis of succession within the strategic, organizational, personal, financial and legal scopes, allowing to determine the readiness for succession.

- Planning app NEO - allows for planning succession-related changes; after considering the results of prior analysis and owners' answers to questions related to the most vital areas of succession, time horizon and successors' preparation, a preliminary plan of succession is generated, including estimated data as to the sequence of tasks and their performance time. Users are allowed to introduce corrections by adjusting such plan to their own individual circumstances.

Consultations concerning this tool were conducted during the period from December 2012 to February 2013, and allowed for gathering opinions of family business owners concerning the challenges of planning succession changes. Said consultations consisted in completing an e-survey or being interviewed by a project moderator at the company seat. Currently, the testing process is being initiated, with the purpose of familiarizing the project participants with individual elements of the so developed Przewodnik po sukcesji [A Guide on Succession], allowing for assessment of efficiency and applicability of said tool in succession planning. An entrepreneur asked to test the Guide will be allowed to familiarize themselves with its contents individually, at any location with computer access. Any remarks concerning the tested tool will be reported as a survey or interview. Those will enable tool improvement.

The testing stage involves 20 seminars for 300 family business owners, 2 nationwide conferences for 300 company owners and those interested in the subject matter, 8 workshops covering the practical application of the Guide for 96 company owners and participation in $5 \mathrm{SME}$ sector conferences regarding supporting family businesses [www.sukcesja.org/].

Another project dedicated to succession in family businesses, currently under testing, is the Kody wartości [Codes of Values] project [www.sukcesja.org.pl].

The tool developed as part of this project is composed of:

- compendium on succession,

- SOS guide - in cases of emergency succession,

- motivating and instructing cartoon series presenting the story of "Delikatesy Dobre" company undergoing succession, run by the Sierpiński family,

- audiobook presenting the story of the Sierpiński family who run a company currently undergoing the process of succession,

- 58 tools supporting the individual stages of the process of succession,

- information service, including, inter alia, case studies, tools, articles, studies, forum, job market for successors. 
During project diagnosis, conducted between $1^{\text {st }}$ November 2012 and $9^{\text {th }}$ February 2013, 8 key factors determining family business success were identified [Kody wartości, p. 21]:

1. Realizing that "this is what is going to happen" and that the sooner we understand it, the greater the probability of succeeding.

2. Analysis of company's initial situation.

3. Initiating talks on succession.

4. Honest conversation with family members and potential successors about concerns involved and subsequent compromise.

5. Necessity of sharing responsibility for the company before transferring the powers.

6. Realizing that the successor is still learning and may make mistakes which do not make him/her incompetent or unprepared.

7. Finding an expert on legal matters and improving communication and understanding of the succession process when this becomes problematic.

8. Planning one's activities after company transfer beforehand.

This tool may be tested after its downloading directly from the website and completing a test survey. The website includes testing tools for diverse groups of users: owners-seniors, management, family members, successors, employees and customers.

Testing the tools described above, developed as part of the Przewodnik po sukcesji and Kody wartości projects, may bring about mutual benefits both to the scientific community and to the family business owners. Common involvement and exchange of experience will allow for tool improvement and, in the nearest future, the subject of succession in Polish family enterprises may cease to be a taboo.

\section{Conclusion}

There will be more and more tools similar to those described above on the Polish market. The information gap concerning succession is perceived not only by the parties directly interested in transferring their lifetime achievements to next generations, but also by external parties for whom training and counselling within this scope will become a source of considerable income.

Currently, family businesses have the opportunity to use the tools free of charge thanks to EU support within the framework of the Human Capital Operational Programme. We are truly hoping that the next EU funding period for Poland for 2014-2020 will bring about more similar projects, adjusted to the specificity of family business. 


\section{Bibliography:}

Główny Urząd Statystyczny (2014), Działalność przedsiębiorstw niefinansowych w 2012 roku, Press conference materials of $23^{\text {rd }}$ December 2013, Warsaw.

Główny Urząd Statystyczny (2013), Zmiany strukturalne grup podmiotów gospodarki narodowej $w$ rejestrze REGON, I pótrocze 2013, Warsaw.

Jakubowski J. (2012), Założenia metodyki 6S, In: Firma $w$ rodzinie czy rodzina $w$ firmie. Metodologia wsparcia firm rodzinnych, PARP, Warsaw.

Mączyńska M. (2012), Projekt „Firmy rodzinne” - geneza, struktura, przyszłość, In: Firma w rodzinie czy rodzina w firmie. Metodologia wsparcia firm rodzinnych, PARP, Warsaw.

Ministerstwo Rozwoju Regionalnego (2013), Program operacyjny Kapitał Ludzki, Warsaw.

Polska Agencja Rozwoju Przedsiębiorczości (2009), Badanie firm rodzinnych. Raport końcowy, Warsaw.

European Commission, (2009), Enterprise and Industry Directorate-General, Promotion of SMEs' competitiveness, Final report of the expert group overview of Familybusiness-relevant issues: Research, networks, policy measures and existing studies.

www.funduszeeuropejskie.gov.pl

www.kapitalludzki.gov.pl

www.sukcesja.org/

www.sukcesja.org.pl 